\title{
Energy performance of building heating - theory and reality on the example of educational buildings
}

\author{
Piotr Lis ${ }^{1, *}$, and Anna Lis $^{2}$ \\ ${ }^{1}$ Czestochowa University of Technology, Faculty of Infrastructure and Environment, \\ J.H. Dąbrowskiego 73, 42-201 Częstochowa, Poland \\ ${ }^{2}$ Czestochowa University of Technology, Faculty of Building, \\ J.H. Dąbrowskiego 73, 42-201 Częstochowa, Poland
}

\begin{abstract}
The calculative methods, which are adopted in various fields of engineering, are usually a certain kind of theoretical approximation of reality. The deviations from a full consistency of actual conditions and theoretical assumptions occur also in case of building heating. This work presents the selected results of examinations connected with an annual energy consumption $\mathrm{C}_{\mathrm{H}}$ and annual final energy demand $\mathrm{Q}_{\mathrm{k}, \mathrm{H}}$ for heating and conducted on the group of educational buildings. The presented analysis and its results regard the group including 46 of 50 educational buildings, which form a municipal group of the buildings of this type. The purpose of presented analysis was to examine the influence of possible occurrence and level of differences between the annual energy consumption $\mathrm{C}_{\mathrm{H}}$ and annual final energy demand $\mathrm{Q}_{\mathrm{k}, \mathrm{H}}$ for heating of examined buildings. The realization of this purpose is the basis for further research and analysis aimed at determining the dominant reasons of mentioned differences, establishing their level and propose a calculative method for reducing the differences between the values "picturing" the thermal needs of educational buildings in actual (energy consumption $\mathrm{C}_{\mathrm{H}}$ ) and theoretical (final energy demand $\mathrm{Q} k, \mathrm{H}$ ) conditions.
\end{abstract}

\section{Introduction}

The calculative methods, which are applied in various fields of engineering, are usually a certain kind of theoretical approximation of reality. The main problem, which occurs here, is the degree of consistency of theoretical description of some phenomenon or process with the actual conditions of its course.

The deviations from a full consistency of actual conditions and theoretical assumptions occur also in case of building's heating. The building is considered as a constructional and installation entirety and constitutes a set of many installation, architectonic-building, constructional-material and operational properties, which have a direct or indirect connection with its heating.

\footnotetext{
${ }^{*}$ Corresponding author: piolis@is.pcz.czest.pl
} 
The appearing discrepancies are visible even in quantitative characteristics of heating, i.e. the amount of heat theoretically needed and actually used for that purpose.

Not so long ago, the thermal power $\mathrm{q}$ and the seasonal heat demand $\mathrm{Q}$ in a standard heating season were one of the basic quantities calculated in the projects of heating systems. Several years ago, in the design studies, the value of thermal power was replaced by so-called design heat load, which is calculated according to PN EN ISO 12831:2006. However, there are no obstacles to use still the thermal power in various considerations. A change of methodology in the design calculations regards also the seasonal heat demand (Q) for buildings' heating. Currently, it can be considered that the equivalent of heating demand for heating $Q$ is the annual energy demand for the final energy supplied to the building or part of the building for the heating system in $\mathrm{kWh} /$ year, marked as $\mathrm{Q}_{\mathrm{k}, \mathrm{H}}$. This quantity is used in the energy performance of the building and calculated on the basis EN ISO 13790:2008. "Energy performance of buildings - Calculation of energy use for space heating and cooling". However, it is not too significant for the purposes of conducted considerations, because the discrepancies between the actual conditions and their theoretical representation can still appear, irrespective of applied methodology.

The author in his earlier studies $[4,5,6]$ analyzed the relationship between the seasonal consumption of heat for heating educational buildings and the peak power needed for heating. It was noticed that about $84 \%$ of changes in the seasonal heat consumption $\mathrm{C}_{\mathrm{H}}$ depends on the changes in thermal power q, while $16 \%$ does not depend on the changes of this quantity [5]. This state can be caused by not very accurate consideration of the actual conditions of buildings' heating in the methodology of thermal power q calculation. The described discrepancies between the theory and the reality of heating buildings have become the basis for further analyzes presented later in this article. This time, analyzes are conducted based on calculated and theoretical quantities used in the energy performance of building regulations in Poland.

\section{Energy performance of building in Poland}

In Poland, the methodology for determining the energy performance of building is presented in the Ordinance of the Minister of Infrastructure and Development on the methodology for determining the energy performance of building or part of building and energy certificates. The basic quantity for determining an energy performance calculated here is the quantity $Q_{p}$ - annual demand for non-renewable primary energy for technical systems in $\mathrm{kWh} /$ year. The calculation methodology of this quantity includes heating and ventilation systems, hot water preparation and permanently installed lighting. The main focus of the article is on the building heating system. For this reason, the basic quantity from which the consideration was started is $\mathrm{Q}_{\mathrm{p}, \mathrm{H}}$ - the annual demand for non-renewable primary energy for the heating system. It is calculated taking into account the coefficient input of non-renewable primary energy on producing and delivering of energy or energy carrier $\mathrm{w}_{\mathrm{i}}$. The value of this coefficient substantially depends on the energy policy of the state and disfigures the physical dimension of the annual demand for non-renewable primary energy for the heating system $\mathrm{Q}_{\mathrm{p}, \mathrm{H}}$. This situation means that the calculated value $\mathrm{Q}_{\mathrm{p}, \mathrm{H}}$ of the demand for non-renewable primary energy for the building heating system with the measured energy consumption for heating $\mathrm{C}_{\mathrm{H}}$ can not be compared. Bearing this in mind, it was decided that the most suitable for comparison with the actual energy consumption for the heating building $\mathrm{C}_{\mathrm{H}}$ would be the $\mathrm{Q}_{\mathrm{k}, \mathrm{H}}$ - annual energy demand for the final energy supplied to the building or part of the building for the heating system in $\mathrm{kWh} /$ year. It takes into account the efficiency of the heating system. The calculated annual demand for final energy supplied for heating the building $\mathrm{Q}_{\mathrm{k}, \mathrm{H}}$ was included in the design 
and theoretical quantities. By contrast, directly or indirectly measured energy consumption for heating $\mathrm{C}_{\mathrm{H}}$ up to real size.

The annual energy consumption $\mathrm{C}_{\mathrm{H}}$ for building heating, the amount of which was determined by measurement and, in a sense, "describes the actual conditions of heating". The value of energy consumption $\mathrm{C}_{\mathrm{H}}$ is the effect of, inter alia, the duration of the heating season and the conditions inside and outside of a room. The obtained results of calculations (for example $\mathrm{Q}_{\mathrm{k}, \mathrm{H}}$ ) should correlate with the results of measurements (measured directly or indirectly) $\left(\mathrm{C}_{\mathrm{H}}\right)$ [2-7]. The connection between discussed quantities should be the stronger, the better are rendered the heating conditions and the specificity of an operated object.

Bearing in mind the above, the purpose of the conducted analyzes is to initially examine the relationship between the theoretical quantity $\mathrm{Q}_{\mathrm{k}, \mathrm{H}}$ and the actual quantity $\mathrm{C}_{\mathrm{H}}$ and use of results to improve the methodology of energy performance of buildings.

\section{Description of conducted examinations and analyses}

The presented analysis and its results are a fragment of wider examinations of educational buildings, which were constructed in years 1913-1992. They form a full municipal complex of 50 objects, in which the primary schools and junior high schools are located. The full statistical examinations, which were carried out in years 1992-2016, included all the units of this complex and they were conducted by stages, in cooperation with the Municipal Office. A method of ad hoc statistical census was applied here, with using of selected measures of descriptive statistics and correlation analysis. The statistical observation was carried out by correspondence and direct surveys, interviews, site inspections and personally conducted measurements. The research material obtained in this manner is a primary material, collected especially for the purposes of conducted statistical examinations.

The heating season used in the analyses was characterized by the average outdoor temperature of air for analyzed period and determined area (town) $\Theta_{\mathrm{e}, \mathrm{av}}=(+2.9)^{\mathrm{O}} \mathrm{C}$ and the duration 230 days. This season can be considered as typical for multiannual period in statistical respect (min. 30 years), which was confirmed by a positive result of testing a hypothesis on its statistical typicality. The average temperature inside of heated educational buildings achieved the value $\Theta_{\text {int, av }}=(+19.9)^{\circ} \mathrm{C}$. The average grade of thermal comfort assessment made by the employees and students in examined objects amounted to 3.98 point in 7-point scale (from 1 to 7) and is within so-called thermal comfort zone. The procedure described above was conducted in order to assure that there are no too big differences of temperatures in heated rooms between examined buildings, which could have a significant influence on analyzed values of annual (seasonal) energy consumption $\mathrm{C}_{\mathrm{H}}$ for heating.

In the examined group, 23 educational buildings were provided with heat for heating by HPC (Heat Power Company), while 27 buildings had their own boiler-rooms. Data determining the thermal power $(\mathrm{q})$ for individual objects were obtained from design and operating documentation and from own checking calculations. In case of buildings using the heat supplied from heat-generating plant (remote heating system) the bills for thermal ("ordered") power and for consumed heat were an additional source of information. The amount of energy $\left(\mathrm{C}_{\mathrm{H}}\right)$ consumed in a base heating season (in the year) was determined in two manners, depending on the source supplying the heat to the central heating system. In the buildings equipped with remote systems of central heating the actual energy consumption $\left(\mathrm{C}_{\mathrm{H}}\right)$ was determined on the basis of readings from installed heat meters, with the measuring accuracy not lower than $2 \%$. In case of own gas or coal-coke boiler-rooms, the amount of annual energy consumption $\left(\mathrm{C}_{\mathrm{H}}\right)$ was calculated on the basis of information on fuel consumption in the base heating season, kind of used fuel and its calorific value, average nominal efficiency and estimated average operational efficiency 
of the central heating boilers, kind of losses in the heat production and their average levels for various types of boilers.

The material presented in this work is a fragment of wider analysis and regards 46 of 50 educational buildings, in which the educational institutions are located (data for 4 objects were questionable in the author's opinion). The total amount of heat used for heating of analyzed objects was $\mathrm{Q}=91.840 \mathrm{GJ} / \mathrm{a}$, with their total cubic capacity $\mathrm{V}=675.389 \mathrm{~m} 3$ and heated area $A_{u}=146.013 \mathrm{~m} 2$. Average values of $C_{H, a v}(0.10)$ and $\mathrm{q}_{\mathrm{av}}(0.10)$, calculated after eliminating of $10 \%$ of extreme values of $\mathrm{Q}$ and $\mathrm{q}$, constitute about $96 \%$ of average values for the entire analyzed group. About $70-80 \%$ of analyzed buildings were considered as typical in respects of the actual energy consumption $\left(\mathrm{C}_{\mathrm{H}}\right)$ for heating of rooms and the thermal power (q).

The basic characteristic of this group of buildings is presented in the Table 1. The statistical description of this group does not differ significantly from the description of the entire group of 50 buildings [3]

Table 1. Selected measures of statistical description for the values characterizing 46 of 50 educational buildings forming the municipal group of objects of this type.

\begin{tabular}{|c|c|c|c|}
\hline Value $\mathrm{x}$ & $\begin{array}{l}\text { Average } \\
\text { value } \\
\mathrm{X}_{\text {av }}\end{array}$ & $\begin{array}{l}\text { Standard } \\
\text { deviation } \\
\mathrm{s}(\mathrm{x})\end{array}$ & $\begin{array}{l}\text { Coefficient } \\
\text { of variation } \\
\operatorname{Vk}(\mathrm{x}), \%\end{array}$ \\
\hline Cubic capacity $\mathrm{V}, \mathrm{m}^{3}$ & 14682.37 & 9674.55 & 65.89 \\
\hline Usable area $A_{u}, m^{2}$ & 3194.09 & 2161.41 & 67.67 \\
\hline Number of classrooms $\mathrm{N}_{\mathrm{c}}$, rooms & 21 & 12 & 58.48 \\
\hline Average area of classroom $\mathrm{Ac}_{\mathrm{u}, \mathrm{av}}, \mathrm{m}^{2}$ & 50.36 & 8.45 & 16.78 \\
\hline $\begin{array}{l}\text { Relation of the building external partitions' area to the } \\
\text { building volume } \mathrm{A} / \mathrm{V}, \mathrm{m}^{-1}\end{array}$ & 0.40 & 0.09 & 23.43 \\
\hline Relation of the classrooms' area to the usable area, - & 0.37 & 0.10 & 26.24 \\
\hline Relation of wind. area to the area of facade $A_{w} / A$, - & 0.25 & 0.05 & 21.73 \\
\hline $\begin{array}{l}\text { Weighted average heat transfer coefficient for external } \\
\text { partitions } U_{B}, W /\left(m^{2} K\right)\end{array}$ & 1.27 & 0.20 & 15.63 \\
\hline Thermal power for heating $\mathrm{q}, \mathrm{kW}$ & 323.38 & 235.15 & 72.72 \\
\hline $\begin{array}{l}\text { Index of thermal power for heating of } 1 \mathrm{~m}^{3} \text { of cubic } \\
\text { capacity } \mathrm{q} / \mathrm{V}, \mathrm{W} /\left(\mathrm{m}^{3} \mathrm{a}\right)\end{array}$ & 21.93 & 5.11 & 23.32 \\
\hline $\begin{array}{l}\text { Annual energy demand for the final energy supplied } \\
\text { to the building for the heating system } Q_{k, H}, G J / \text { year } \\
\text { (for } n=1 ; n=3 \text { ) }\end{array}$ & $\begin{array}{l}1599.32(\text { for } \mathrm{n}=1) \\
2002.18(\text { for } \mathrm{n}=3)\end{array}$ & $\begin{array}{l}1068.77 \\
1417.31\end{array}$ & $\begin{array}{l}66.83 \\
64.36\end{array}$ \\
\hline $\begin{array}{l}\text { Index of annual energy demand for the final energy } \\
\text { supplied to the building for the heating system } \\
Q_{k, H} / V, G J /\left(m^{3} a\right)(\text { for } n=1 ; n=3)\end{array}$ & $\begin{array}{l}0.1073(\text { for } \mathrm{n}=1) \\
0.1491(\text { for } \mathrm{n}=3)\end{array}$ & $\begin{array}{l}0.0299 \\
0.0390\end{array}$ & $\begin{array}{l}27.88 \\
26.18\end{array}$ \\
\hline $\begin{array}{l}\text { Annual energy consumption for heating in standard } \\
\text { heating season } \mathrm{C}_{\mathrm{H}}, \mathrm{GJ} / \mathrm{a}\end{array}$ & 1996.52 & 1266.14 & 63.42 \\
\hline $\begin{array}{l}\text { Index of annual energy consumption for heating of } \\
1 \mathrm{~m}^{3} \text { of cubic capacity in standard season }\left(\mathrm{C}_{\mathrm{H}} / \mathrm{V}\right) \text {, } \\
\mathrm{GJ} /\left(\mathrm{m}^{3} \mathrm{a}\right)\end{array}$ & 0.1384 & 0.0393 & 28.37 \\
\hline
\end{tabular}




\section{Results and discussion of examinations' results}

Bearing in mind the realization of article purpose, following important questions arise:

1) Are there discrepancies between the actual and theoretical heating conditions of the analyzed buildings, which are quantitatively characterized by appropriate values?;

2) What is a quantitative range of possible discrepancies?;

3) What may be the reasons of such situation?

Before calculations, the examined buildings were sorted from the smallest to largest annual energy consumption for heating. The energy consumption for building heating is strongly related to its size.

Based on the methodology of energy certification of buildings in Poland and EN ISO 13790:2008. "Energy performance of buildings - Calculation of energy use for space heating and cooling", calculations Q k,H were made. The calculations were made in the arcadia computer program, where the ventilation of the building is described by the number of air changes $\mathrm{n}$. The value $\mathrm{n}$ may be: 1, 2 or 3. Calculations of the energy demand for heating $\mathrm{Q}_{\mathrm{k}, \mathrm{H}}$ were carried out assuming extreme values. The annual final energy demand $Q_{k, H}$ for heating were calculated for $n=1 h^{-1}$ and $n=3 h^{-1}$. In order to give an answer to the first question, the annual final energy demand $\mathrm{Q}_{\mathrm{k}, \mathrm{H}}$ for heating used in energy certification of buildings were compared graphically with the annual energy consumption $\mathrm{C}_{\mathrm{H}}$ for heating (Fig. 1-2).
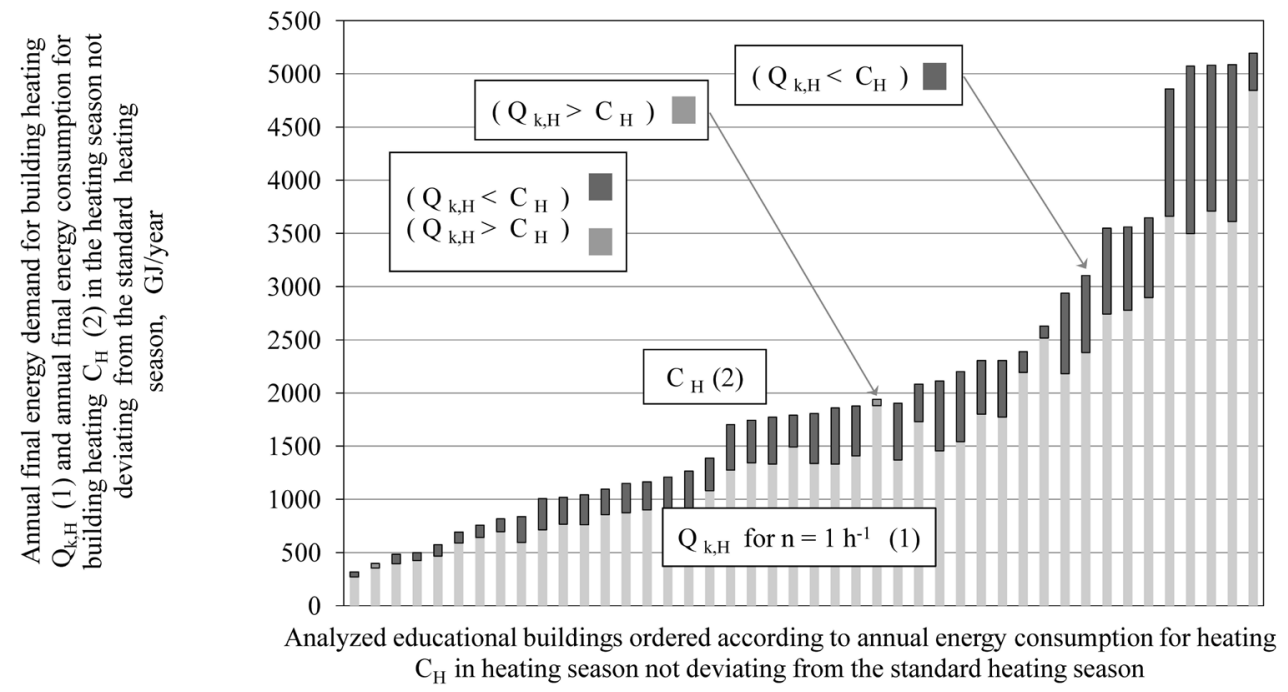

Fig. 1. Annual final energy demand for building heating $Q k, H$ for $n=1(1)$ and annual final energy consumption for building heating $\mathrm{C} \mathrm{H}(2)$ in the heating season not deviating from the standard heating season, GJ/year.

In order to answer the second question, the differences between the theoretical values the annual final energy demand $\mathrm{Q}_{\mathrm{k}, \mathrm{H}}$.for heating, and the actual annual energy consumption $\mathrm{C}_{\mathrm{H}}$ for heating were calculated and presented in Figs. 3-4.

In addition, Fig. 5 show trends in changes in energy demand and energy consumption in educational buildings. Fig. 6 shows the trends of differences between the annual final energy demand and the annual energy consumption for heating $\left(\mathrm{Q}_{\mathrm{k}, \mathrm{H}}-\mathrm{C}_{\mathrm{H}}\right) \cdot 100 \%$. One should remember, however, that the graphs were drawn for the group of buildings diverse in respect of properties, which influence significantly on the amount of heat consumed for heating. The analysis of calculated values and graphs (Fig. 1-6) reveals the 
differences between annual energy consumption $\left(\mathrm{C}_{\mathrm{H}}\right)$ for heating and calculated annual final energy demand $\left(\mathrm{Q}_{\mathrm{k}, \mathrm{H}}\right)$.
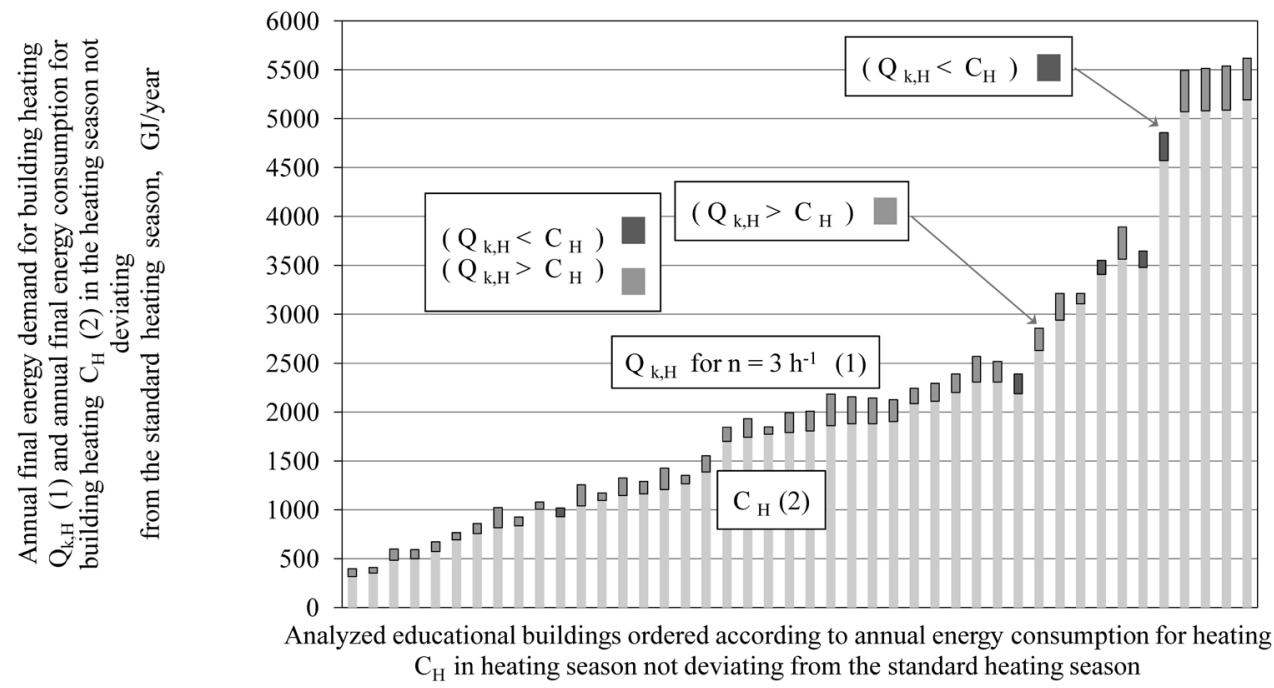

Fig. 2. Annual final energy demand for building heating $Q_{k, H}$ for $n=3$ (1) and annual final energy consumption for building heating $\mathrm{C}_{\mathrm{H}}(2)$ in the heating season not deviating from the standard heating season, GJ/year

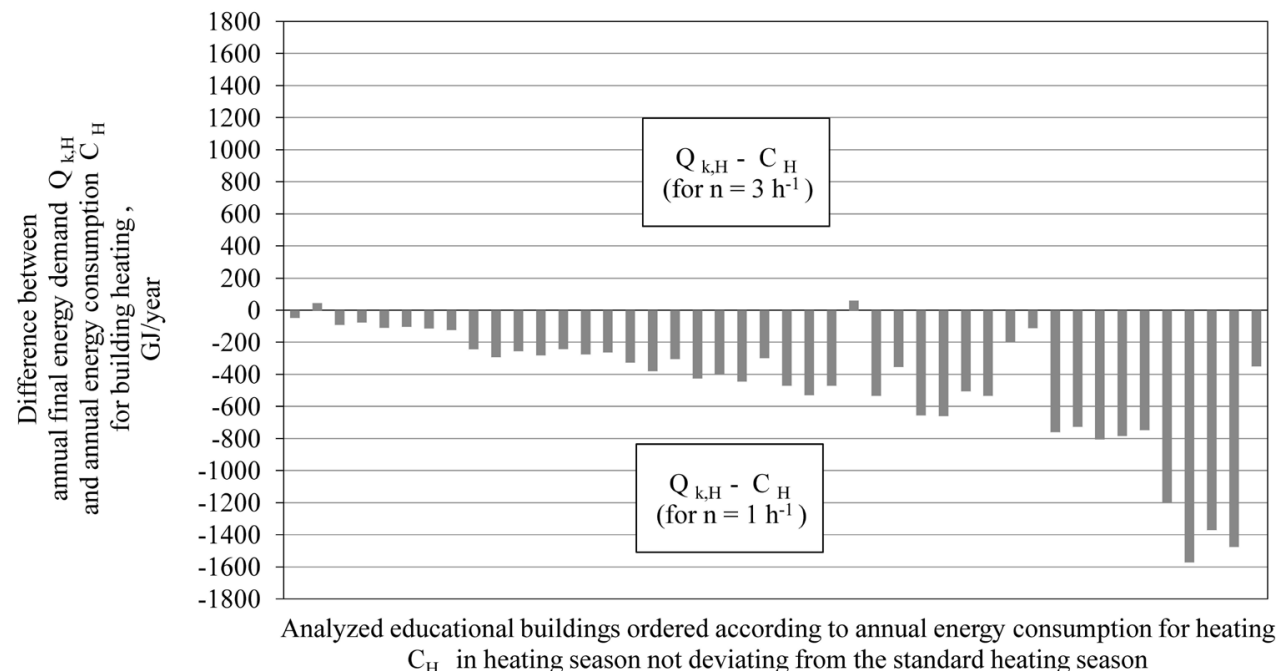

Fig. 3. Differences between annual final energy demand for building heating $\mathrm{Q}_{\mathrm{k}, \mathrm{H}}$ for $\mathrm{n}=1$ (1) and annual final energy consumption for building heating $\mathrm{C}_{\mathrm{H}}(2)$ in the heating season not deviating from the standard heating season, GJ/year

Occurrence of these differences confirms the course of trend lines for changes in analyzed quantities, which are shown on the graphs - Fig. 6. Calculated annual final energy demand $\mathrm{Q}_{\mathrm{k}, \mathrm{H}}$ for $\mathrm{n}=3 \mathrm{~h}^{-1}$ is bigger by $11.4 \%$ and $192.2 \mathrm{GJ}$, on the average, than the actual energy consumption for heating $C_{H}$, but final energy demand $Q_{k, H}$ for $n=1 h^{-1}$ is smaller by $20.9 \%$ and $450.0 \mathrm{GJ}$, on the average, than the actual energy consumption for heating $\mathrm{C}_{\mathrm{H}}$. However, there are few buildings, in which the situation is opposite. 


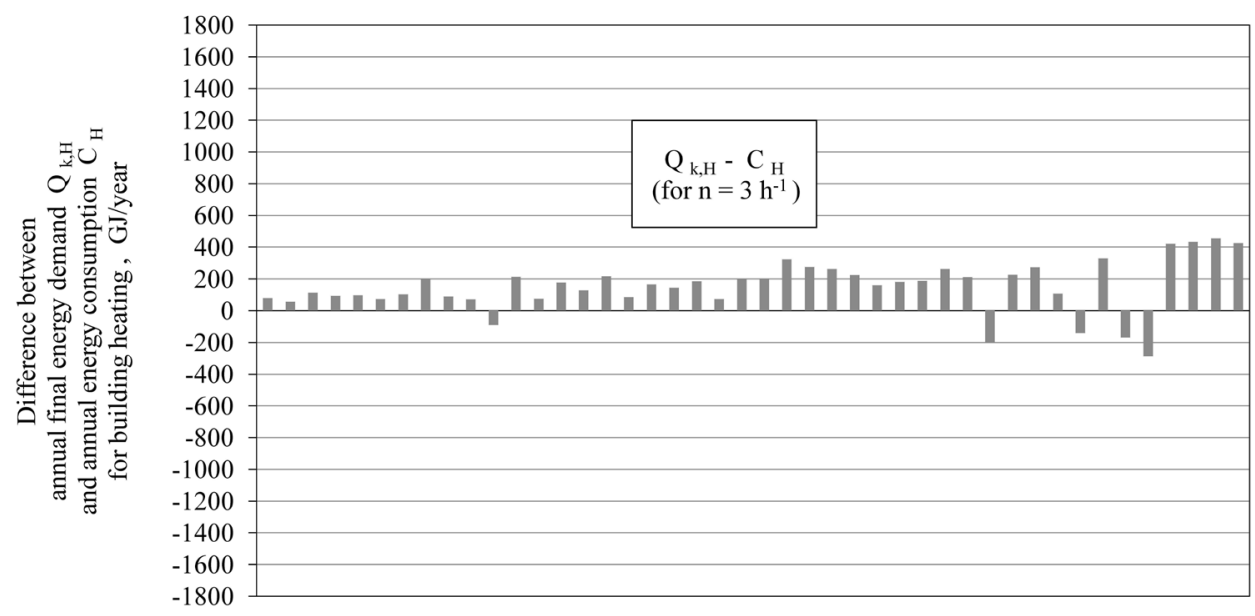

Analyzed educational buildings ordered according to annual energy consumption for heating $\mathrm{C}_{\mathrm{H}}$ in heating season not deviating from the standard heating season

Fig. 4. Differences between annual final energy demand for building heating $\mathrm{Q}_{\mathrm{k}, \mathrm{H}}$ for $\mathrm{n}=3$ (1) and annual final energy consumption for building heating $\mathrm{C}_{\mathrm{H}}(2)$ in the heating season not deviating from the standard heating season, GJ/year
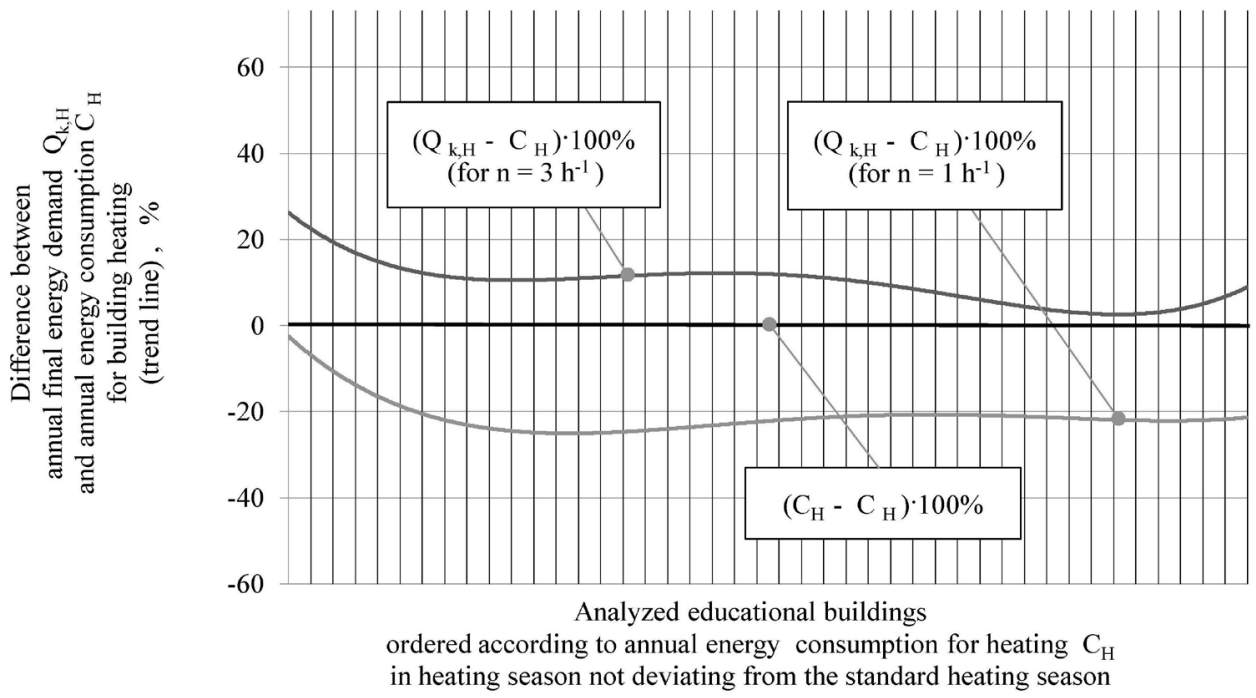

Fig. 5. Trend line for annual final energy demand for building heating $\mathrm{Q}_{\mathrm{k}, \mathrm{H}}(1)$ in analyzed educational buildings ordered according to growing annual energy consumption for heating $\mathrm{C}_{\mathrm{H}}$ in heating season not deviating from the standard heating season, $\mathrm{GJ} /$ year

The courses of trend lines for the theoretical value $\left(\mathrm{Q}_{\mathbf{k}, \mathrm{H}}\right)$ and for actual energy consumption for heating $\left(\mathrm{C}_{\mathrm{H}}\right)$ are similar on all graphs, with presented in Fig. 7. In each of cases presented in Fig. 7, the directions of trend lines for analyzed quantities are less or more divergent. It means that the increase of calculated value $\left(\mathrm{Q}_{\mathbf{k}, \mathrm{H}}\right)$ is quicker than the increase of the actual energy consumption for heating $\left(\mathrm{C}_{\mathrm{H}}\right)$. Simultaneously, it causes the increase of the value of differences $\left(\mathrm{Q}_{\mathrm{k}, \mathrm{H}}-\mathrm{C}_{\mathrm{H}}\right)$ for these objects. 

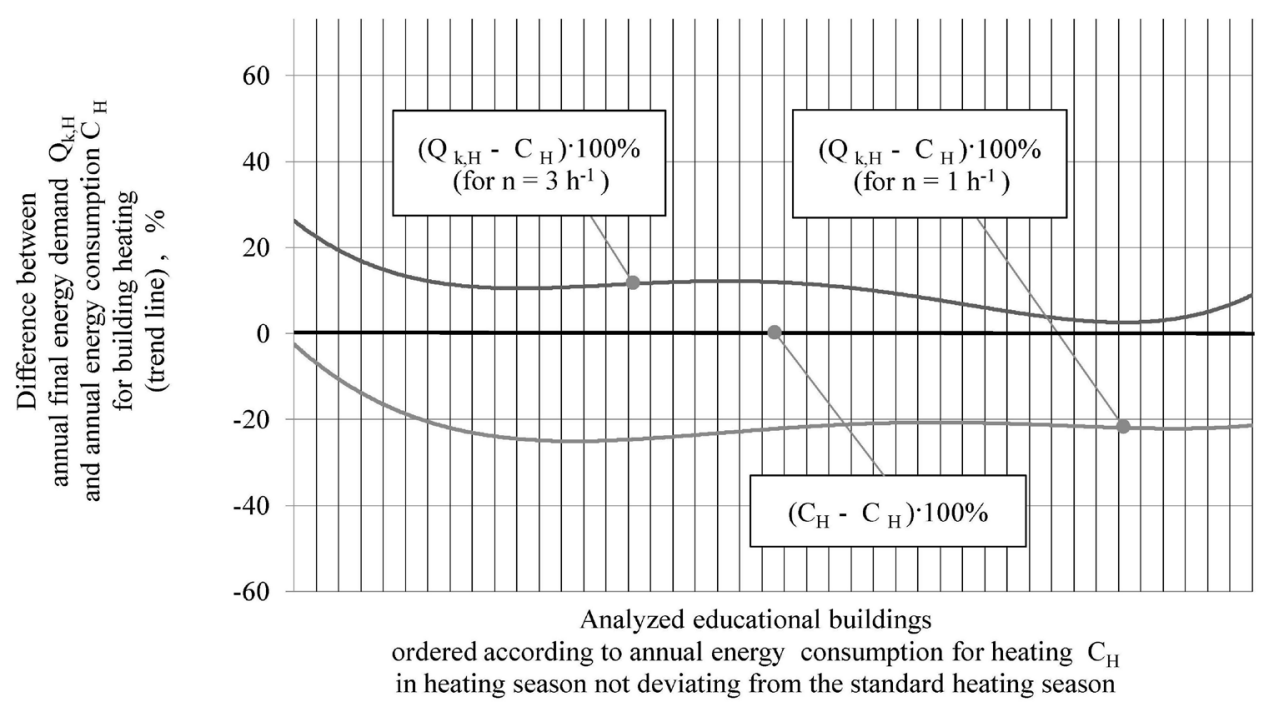

Fig. 6. Trend line for difference between annual final energy demand $\mathrm{Q}_{\mathrm{k}, \mathrm{H}}(1)$ and annual energy consumption $\mathrm{C}_{\mathrm{H}}(2)$ for heating in analyzed educational buildings ordered according to growing annual energy consumption for heating $\mathrm{C}_{\mathrm{H}}$ in heating season not deviating from the standard heating season, \%

\section{Summary}

To sum up, it can be repeated that the occurrence of differences between the annual energy consumption $\left(\mathrm{C}_{\mathrm{H}}\right)$. and the annual final energy demand $\left(\mathrm{Q}_{\mathrm{k}, \mathrm{H}}\right)$ for buildings heating, calculated in proposed manner, was found. The quantitative level $\left(\mathrm{Q}_{\mathrm{k}, \mathrm{H}}-\mathrm{C}_{\mathrm{H}}\right)$ is different in analyzed educational buildings. It does not result only from the differences between the methodology of $\mathrm{Q}_{\mathbf{k}, \mathrm{H}}$ calculation and the actual heating process, which results in generating of the annual energy consumption $\left(\mathrm{C}_{\mathrm{H}}\right)$ for heating of the examined buildings. If it is so, then it seems that the points of data for individual buildings should overlap with the trend of changes in $\mathrm{Q}_{\mathrm{k}, \mathrm{H}}$ and $\mathrm{C}_{\mathrm{H}}$ values (Fig. 1, 2, 3, 4).

A phenomenon, which was observed for several buildings and consists in a considerable diversity between the values of annual final energy demand $\left(\mathrm{Q}_{\mathrm{k}, \mathrm{H}}\right)$ and annual energy consumption $\left(\mathrm{C}_{\mathrm{H}}\right)$ for heating in relation to its average level, in connection with presented results, may prove:

- an incorrect making energy certificate and incorrect assumptions used in calculating the values of annual final energy demand $\mathrm{Q}_{\mathrm{k}, \mathrm{H}}$ for the part of objects or incorrect determination of thermal power (q). Such errors may be a reason of insufficient heating of educational buildings or paying of excessive fixed duties for thermal power (q);

- an improper operation of schools in the scope of appropriate ventilation of rooms, which is always connected with cubic capacity of examined buildings, mentioned here.

Proposed comparison of the theoretical $\left(\mathrm{Q}_{\mathrm{k}, \mathrm{H}}\right)$ and actual $\left(\mathrm{C}_{\mathrm{H}}\right)$ values and the graphical methods applied in the analysis may be used in order to determine the scope of such incorectnesses, in the analysis of heating of similar groups of educational buildings and also as a help in providing other information connected with the specificity of such objects' heating. A relation of the difference's value $\left(\mathrm{Q}_{\mathrm{k}, \mathrm{H}}-\mathrm{C}_{\mathrm{H}}\right)$ to the value of $\mathrm{C}_{\mathrm{H}}$ expressed in GJ and percentage is also diverse in individual objects.

The values specified above have a certain common property, which is a direct or indirect connection with the size of examined buildings. During the years 1913 - 1992, 
when the analyzed objects were constructed, a tendency toward the construction of bigger and bigger educational objects was noticed. All these reasons incline to the interpretation that presented relationships are, to a bigger or smaller degree, determined by the size of examined objects, which is described quantitatively by their cubic capacity (V) and the factors connected with that. Thus, the cubic capacity of examined objects has a significant and often dominant influence on analyzed relationships. Certainly, an accurate determination of the operation of a building's ventilation system is very important for the correctness of its energy performance. The adoption of an incorrect amount of ventilation air will cause too unfavorable or advantageous energy characteristics of the analyzed building. Such cases often appear in the performance of energy certificates by people with little professional experience. In this context, it would be best to make measurements allowing indirect or direct determination of the actual operation of the ventilation system. Such measurements should be made before calculations related to the energy performance of the building.

Does this diversity remain dependant on other certain factors characterizing the selected objects, such as, inter alia, the architectonic shape of a building, energy consumption by heating and thermo-insulating power of external particles? Answers to this question will need to be made during further research and analysis aimed at determining the dominant reasons of mentioned differences, establishing their level and propose a calculative method for reducing the differences between the values "picturing" the thermal needs of educational buildings in actual (energy consumption $\mathrm{C}_{\mathrm{H}}$ ) and theoretical (final energy demand $\mathrm{Q}_{\mathrm{k}, \mathrm{H}}$ ) conditions.

Acknowledgements: The material was prepared as part of the statutory research of the Czestochowa University of Technology BS / PB-407-302 / 11 task 6.

\section{References}

1. Rozporządzeniu Ministra Infrastruktury i Rozwoju z dnia 27 lutego 2015 r. w sprawie metodologii wyznaczania charakterystyki energetycznej budynku lub części budynku oraz świadectw charakterystyki energetycznej (Dz.U. 2015 poz. 376, Warszawa 2015 z późniejszymi zmianami)

2. S.P. Corgnati, V. Corrado, M. Filippi, Energy and Buildings, A method for heating consumption assessment in existing buildings: A field survey concerning 120 Italian schools. 40, 801-809 (2008)

3. K. Karperkiewicz K., Czasopismo Techniczne - Budownictwo 5-B, Ocena potrzeb cieplnych budynku na podstawie monitoringu dostarczanej energii, 251-258 (Wydawnictwo Politechniki Krakowskiej, Kraków 2006)

4. P. Lis, Seria Monografie nr 263, Cechy budynków edukacyjnych a zużycie ciepła do ogrzewania, (Wydawnictwo Politechniki Częstochowskiej, Częstochowa 2013)

5. P. Lis, Environmental Engineering, The actual and calculated thermal needs of educational buildings, 405-416 (Taylor \& Francis Group, London, 2013)

6. P. Lis, A. Lis, Czasopismo Techniczne - Budownictwo 3-B, The seasonal heat demand for heating, calculated on the basis of peak power values in educational buildings, 281-289 (Wydawnictwo Politechniki Krakowskiej, Kraków 2014)

7. P. Lis P., J. Piesyk, Fizyka budowli w teorii i praktyce, IX, 3, Energy consumption and final energy demand for heating in educational buildings - identification of the problem, 19-26, 2017 